This report was prepared as an account of work sponsored by an agency of the United States Government. Neither the United States Government nor any agency thereof, nor any of their employees, makes any warranty, express or implied, or assumes any legal liability or responsibility for the accuracy, completeness, or usefulness of any information, apparatus, product, or process disclosed, or represents that its use would not infringe privately owned rights. Reference herein to any specific commercial product, process, or service by trade name, trademark, manufacturer, or otherwise does not necessarily constitute or imply its endorsement, recommendation, or favoring by the United States Government or any agency thereof. The views and opinions of authors expressed herein do not necessarily state or reflect those of the United States Government or any agency thereof.

\title{
ACHIEVING MAJOR ENERGY EFFICIENCY IMPROVEMENTS IN MANUFACTURED HOUSING
}

\author{
A. D. Lee \\ S. A. Onisko \\ W. K. Lloyd Jr.
}

March 1992

Presented at the 10th Annual International Energy Efficient Building Conference and Exposition Research

March 4-7, 1992

Triangle Park, North Carolina

Work supported by the U.S. Department of Energy under Contract DE-ACO6-76RLO 1830

Pacific Northwest Laboratory

Richland, Washington 99352

\section{MASTER}

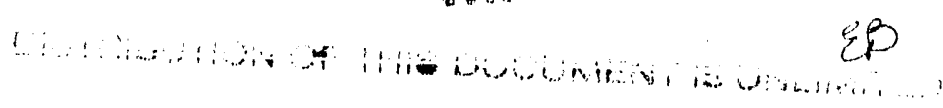




\section{SUMMARY}

In the Residential Construction Demonstration Project (RCDP), the Bonneville Power Administration (BPA) worked with regional manufacturers to build 150 manufactured homes that met the Northwest Power Planning Council's (NWPPC's) Model Conservation Standards (MCS) for residential energy efficiency. Data on energy use and cost-effectiveness were analyzed, and the experiences of manufacturers, dealers, and consumers were studied. This paper discusses the findings of the project and looks at the future of energy-efficient manufactured housing.

\section{INTRODUCTION}

In the Residential Construction Demonstration Project (RCDP), the Bonneville Power Administration (BPA) worked with regional HUD-code manufactured home (mobile home) producers to build 150 energy-efficient homes. They were constructed to meet the Northwest Power Planning Council's (NWPPC's) Model Conservation Standards (MCS) for electrically heated homes. Data on energy use, incremental construction costs, and infitration rates were obtained and analyzed, and the experiences of manufacturers, dealers, and consumers were studied.

The design standards for the RCDP homes varied depending on the climate of their destination. The MCS established design standards for the three climate zones typical of the Northwest. Zone 1 , with fewer than 6,000 heating degree-days (HDD) per year, ${ }^{\left({ }^{\mid a}\right)}$ is the mildest and most populated climate zone. Zone 2 has 6,000 to $8,000 \mathrm{HDD}$. Zone 3, with greater than 8,000 HDD, is the coldest and least populated zone. MCS efficiency requirements are least strict in zone 1 and most strict in zone 3 . Only five homes were constructed for zone 3 during the RCDP.

Manufacturers used two alternative ways to meet the RCDP specifications. In the first, manufacturers greatly reduced the rate of heat loss from the home by installing extra insulation and energy-efficient windows. In the second, manufactures installed a lesser amount of extra insulation, but used a heat pump instead of electric resistance heating. ${ }^{(b)}$

The MCS require improvements in energy efficiency well beyond the minimum requirements of the HUD code. Prior to the RC,DP, a major concern shared by the industry and BPA was whether homes could be constructed to meet demanding energy-efficiency requirements. Table 1 compares the typical energy conservation measures (ECMs) required to meet the HUD code in the Pacific Northwest with the ECMs typically offered to buyers (base-case) and the ECMs usually installed under the RCDP. The 150

(a) A degree day is a unit of accumulated temperature departure, based on temperature difference and time, used in estimating fuel consumption and specifying nominal heating load of a building in winter. For any one day, the number of heating degree days equals the number of degrees of temperature difference between a given base temperature (usually $65^{\circ} \mathrm{F}$ ) and the mean outside temperature over 24 hours.

(b) The results for homes with heat pumps are not discussed here because this paper focuses on envelope improvements rather than heating equipment. 
homes built in the RCDP demonstrated that the industry could produce homes with significant improvements in energy efficiency.

TABLE 1. Comparison of Energy Conservation Measures

\begin{tabular}{||l|l|l|l|}
\hline $\begin{array}{l}\text { Envelope } \\
\text { Component }\end{array}$ & $\begin{array}{l}\text { Typical Minimum } \\
\text { Levels to Meet HUD } \\
\text { Code }\end{array}$ & $\begin{array}{l}\text { Typical Base } \\
\text { Case Levels }\end{array}$ & Typical RCDP Levels \\
\hline \hline Floor & R-7 insulation & R-11 insulation & R-30 insulation \\
\hline Walls & R-11 insulation & R-11 insulation & R-19 insulation \\
\hline Ceiling & R-11 insulation & R-14 insulation & R-38 insulation \\
\hline Windows & $\begin{array}{l}\text { Dual-pane, } \\
\text { aluminum frame }\end{array}$ & $\begin{array}{l}\text { Dual-pane, } \\
\text { aluminum frame }\end{array}$ & $\begin{array}{l}\text { Dual-pane, vinyl frame (some } \\
\text { with argon fill) or dual-pane, } \\
\text { aluminum frame with storm }\end{array}$ \\
\hline
\end{tabular}

Computer simulations and measured consumption data were used to compare RCDP homes with homes constructed to the base-case energy-efficlency levels offered by each manufacturer, or the base case. $^{|a|}$

Manufacturers were interviewed twice during the course of the RCDP, once soon after producing their first home to meet the requirements and again at the conclusion of the project. The knowledge gained from the RCDP was used to establish the technical, information, and funding requirements for including manufactured homes in BPA's Super Good Cents (SGC) marketing and incentives program.

This paper discusses the findings of the project and provides information that should be useful in the development of future energy-efficient manufactured housing programs in the Northwest and nationwide.

\section{MANUFACTURED HOME PRODUCTION PROCESS CHANGES}

Before the start of the RCDP, manufacturers were concerned that they would not be able to produce homes to the MCS levels without major changes to their production process. However, they found that modifying designs of their existing models enabled them to meet the program requirements, so that none of the RCDP homes were totally new designs (Riewer and Lee 1990). Thus, major

(a) Note that the base-case efficlency levels were not the minimum levels permitted under the HUD standards. The base case levels exceeded the minimum energy efficiency allowed by the code by 10 to " $5 \%$; these higher levels reflected the fact that market demand exists for higher efficlency levels. 
overhauls of manufacturers' established production processes wele not necessary. Manufacturers did face a number of smaller hurdles, however.

The RCDP homes required a number of new products because some of the manufacturers' standard products (such as standard windows) were either too inefficient to use in the RCDP homes or because the RCDP requirements specified particular designs, as in the case of ventilation systems. This created two problems: First, manufacturers had to find suppliers for the new products. Second, because manufacturers continued producing their regular homes in addition to the RCDP homes, finding storage space and covering inventory costs of the new products sometimes presented problems (Riewer and Lee 1990).

Initially, manufacturers often had trouble deciding which measures to use to meet the strict requirements and what tradeoffs to make among the measures. As Table 1 showed, insulation levels of walls, floors, and ceilings were usually increased and improved windows were installed. Even with these improvements, manufacturers found it difficult to meet overall heat loss requirements if they installed the maximum window area allowed under the RCDP, $15 \%$ of total floor area, especially in the coldest zone (zone 3 ) where requirements were the most strict. ${ }^{(a)}$ To compensate, manufacturers usually reduced the window area of the homes, sometimes to as little as 10\% (BPA 1991a).

While no major overhauls of the production process were necessary, some minor changes were. Production processes had to be modified to coordinate the improved insulation with wiring and air sealing. The modifications did not require any significant changes to the work stations, however, nor did they require any new equipment (BPA 1990).

\section{ENERGY USE AND VENTILATION RATE DATA ACQUISITION}

Data were collected from three meters installed in the RCDP homes. One meter, placed across the furnace electrical circuit, monitored the heating energy used by the home. A second meter measured water heater energy use. The third meter used in collecting energy data was the utility company's meter (BPA 1991a, pp. 25-26).

Occupants reported their thermostat temperature setpoints for daytime, nighttime, and times when they were away from home. Field audits were performed where actual thermostat settings, window orientations, and heating system types were noted (BPA 1991a pp. 26-27).

Ventilation rates were also measured during the field studies using perfluorocarbon tracer gas tests. The combination of natural infiltration and mechanical ventilation yielded the measured air exchange rates. Blower door tests were used to measure leakage areas (Hadley and Bailey 1990).

(a) The heat loss rate of even the most efficient windows installed in the RCDP was nearly 10 times greater than the surrounding wall area. 
The data on living conditions were combined with actual weather data for during the periods in which the homes were monitored, and input to a computer program to produce adjusted energy use estimates. The estimated energy use was compared to the actual energy use of the homes to determine the accuracy of the computer predictions.

\section{ESTIMATED ENERGY SAVINGS OF RCDP HOMES}

A computer program was used to compare estimated electrical space heating energy use for homes designed to RCDP requirements with homes built to base-case and the minimum HUD-code energy-efficiency levels. Table 2 shows the results of the computer simulation, which indicate that the RCDP homes produced space heating energy savings ranging from $43 \%$ to $49 \%$ when compared with base-case manufactured homes. Compared with the minimum HUD-code efficiency levels, the energy savings were over $50 \%$ higher in all zones. The percentage savings were largest in the mildest climate zone, zone 1. The estimated heat loss coefficient, $U_{0}$ decreased about $31 \%$. Insulation of the heating and crossover ducts were major contributors to energy savings, accounting for 10 to $20 \%$ of the total savings (BPA 1991a, p. 23)!

TABLE 2. Comparisons of Estimated Space Heating Energy Use and Savings

\begin{tabular}{||l|l|l|l|l||}
\hline \multirow{2}{*}{$\begin{array}{l}\text { Home Type, Space Heating and } \\
\text { Savings }\end{array}$} & \multicolumn{3}{|c|}{ kWh per Year } & \multirow{2}{*}{$U_{0}$} \\
\cline { 2 - 4 } & Zone 1 & Zone 2 & Zore 3 & \\
\hline $\begin{array}{l}\text { Minimum HUD-code, space } \\
\text { heating }\end{array}$ & 13,800 & 19,900 & 23,500 & 0.126 \\
\hline Base case, space heating & 10,900 & 16,200 & 19,100 & 0.108 \\
\hline RCDP, space heating & 5,600 & 9,200 & 10,900 & 0.074 \\
\hline $\begin{array}{l}\text { RCDP compared with minimum } \\
\text { HUD-code, energy savings }\end{array}$ & $\begin{array}{l}8,200 \\
(59 \%)\end{array}$ & $\begin{array}{l}10,700 \\
(54 \%)\end{array}$ & $\begin{array}{l}12,600 \\
(54 \%)\end{array}$ & N/A \\
\hline $\begin{array}{l}\text { RCDP compared with base } \\
\text { Case, energy savings }\end{array}$ & $\begin{array}{l}5,300 \\
(49 \%)\end{array}$ & $\begin{array}{l}7,000 \\
(43 \%)\end{array}$ & $\begin{array}{l}8,200 \\
(43 \%)\end{array}$ & N/A \\
\hline
\end{tabular}

The RCDP homes were monitored for energy use after they were set up at their final destination to see how measured space heating energy use compared with estimated energy use. After modifying weather data to account for actual conditions, the predicted and measured values agreed, on the average, to within $5 \%$. When occupancy assumptions, window locations, and infiltration rates were adjusted to match conditions as reported by occupants and measured in field studies, the agreement 
was within $2 \%$ on the average (BPA 1991a, pp. 29). Thus, the computer program was able to accurately predict the average space heating energy use of the homes.

\section{VENTILATION IN RCDP HOMES}

Current manufactured housing construction practices produce homes that are somewhat tighter than site-built homes (Ek, Onisko, and Gregg 1990). Consequently, the inflitration rates in manufactured homes were low before the start of the RCDP. Under the RCDP, the rates were reduced further.

The mean air exchange rate for the RCDP homes was 0.23 air changes per hour (ach). Two groups of "current practice" homes were also tested, with mean air exchange rates of 0.30 ach and 0.27 ach (Hadley and Bailey 1990). The majority of both the RCDP homes and "current practice" homes that were tested for infiltration falled to meet the minimum ventilation rate of 0.35 ach recommended by ASHRAE standards (Hadley and Balley 1990). Although speclal ventllation requirements were established for the RCDP, improper installation and incorrect operation reduced their effectiveness.

Two types of whole-house ventilation systems were used in the RCDP homes. The first type was an integrated whole-house/bath fan system. The second type was a discrete whole-house ventilation system. Only nine of the RCDP homes had the latter system. Each system included inlet vents located throughout the home to provide make-up fresh air.

A large majority of the homes, 121 , also had a furnace fresh-air system that is a commonly installed option in manufactured homes. The system is designed to provide at least 25 cubic feet per minute of fresh air when the furnace is operaing. Field test results, however, measured no air flow through these systems in 35 of the RCDP homes (Hadley and Bailey 1990, p. 4.4).

Problems with the installation and operation of the fresh-air systems resulted in ineffective ventilation. Problems included closed vents, ventilation system timers that were either nonfunctional or not set to operate, ducts that were pinched off during installation severely restricting airflow, inoperable dampers that were jammed closed, and dirty furnace filters (Hadley and Balley 1990).

The low air exchange rates of the homes indicate that the mechanical ventilation systems as they were installed and operated did not provide the needed ventilation. Because this could aggravate potential indoor air quality, moisture, and condensation problems, BPA is in the process of developing specifications designed to remedy potential problems. 


\section{COST-EFFECTIVENESS RESULTS}

Based on wholesale cost data collected during the RCDP, the retall costs of all ECMs were calculated. The first cost and energy savings data were used to estimate levelized costs of the ECMs. ${ }^{\text {(a) }}$ The levelized costs were calculated using the following assumptions (BPA 1991b, p. 3):

- a 45-year life expectancy for all envelope measures except windows

- a 30-year life expectancy for windows (total replacement at 30 years)

- an annual real discount rate of $3 \%$.

Table 3 summarizes the incremental costs of upgrading the homes in the RCDP from the basecase levels. It also presents the levelized costs associated with the energy savings for the homes. The results are shown for each of the three climate zones in the Pacific Northwest. While retail costs increased for the colder climate zones, increased energy savings in these reglons resulted in lower levelized costs for the ECMs.

TABLE 3. First Costs and Levelized Costs ${ }^{(a)}$

\begin{tabular}{|l|l|l|l||}
\hline Climate Zone & $\begin{array}{l}\text { Average Annual Space } \\
\text { Heating Savings, kWh }\end{array}$ & $\begin{array}{l}\text { Incremental Retail } \\
\text { Cost }^{(\mathrm{b})}\end{array}$ & $\begin{array}{l}\text { Levelized Cost of } \\
\text { Savings, } \$ / \mathrm{kWh}\end{array}$ \\
\hline \hline 1 & 5,300 & $\$ 3,851$ & 0.030 \\
\hline 2 & 7,000 & $\$ 4,552$ & 0.027 \\
\hline 3 & 8,200 & $\$ 4,916$ & 0.024 \\
\hline
\end{tabular}

(a) The information in this table was taken from BPA 1991a and modifled based on data in Ecotope 1991.

(b) These costs include the present discounted value of future costs.

The effect of the ECMs on first-year cash-flow was also evaluated assuming the money was borrowed on a 20 -year loan at $13 \%$ interest, representative of current lending terms. The yearly financing cost of the measures was subtracted from the money saved due to the reduced energy costs, and incremental effects of property taxes and income tax deductions were taken into account, resulting in an incremental "cash flow" for the first year. ${ }^{(b)}$ Positive cash flow indicates a net benefit to the buyer.

(a) Levelized costs convert the incremental cost of consenvation measures to an equivalent cost per unit of energy saved by the measure over its lifetime.

(b) Finance charges were calculated on an annual basis. It was assumed that the buyer would finance the entire cost of the measures to avold the non-recurring effect of down payment on firstyear cash flow. Energy cost savings were calculated based on a reglonal average electricity price of $\$ 0.0508 / \mathrm{kWh}$. 
Table 4 shows that without monetary incentives to elther the buyer (retail level) or manufacturer (wholesale level), the increased cost to the buyer was greater than the money saved in all climate zones, resulting in a negative first-year cash flow. However, with the SGC program incentlves $(\$ 2,000$ to the buyer in zone $1, \$ 2,500$ in zone 2, and $\$ 3,000$ in zone 3), the first-year cash flow was positive in all cases.

TABLE 4. Buyer First-Year Cash Flow Comparisons

\begin{tabular}{||l|l|l|}
\hline Climate Zone & $\begin{array}{l}\text { First-Year Cash } \\
\text { Flow with No } \\
\text { Incentlve }\end{array}$ & $\begin{array}{l}\text { Firsi-Year Cash } \\
\text { Flow with SGC } \\
\text { Buyer Incentive }\end{array}$ \\
\hline 1 & $-\$ 171$ & $\$ 59$ \\
\hline 2 & $-\$ 165$ & $\$ 122$ \\
\hline 3 & $-\$ 148$ & $\$ 197$ \\
\hline
\end{tabular}

Table 5 shows the cash flow "break-even" incentive levels. These quantities are the incentive leveis that would be required to offset the incremental cost of ECMs enough to just make the first-year cash flow positive. The table shows that the break-even buyer incentive required at the retail level is between about $\$ 1,200$ and $\$ 1,500$, depending on climate zone. Because manufactured homes are sold through retall dealers who add a markup to the wholesale price, an incentive to the manufacturer can have more of an effect on retail price. The table shows that, accounting for the multiplier effect (Harkreader, Lee, and Sherman 1987, p. 4.11), the size of the incentive required for a positive iirst-year cash flow could be reduced by about $30 \%$ if the payment went to the manufacturer instead of the buyer.

TABLE 5. Minimum Incentive Required for Buyer Positive Cash Flow in the First Year

\begin{tabular}{||l|l|l|}
\hline Climate Zorie & $\begin{array}{l}\text { Required Incentive Payment to } \\
\text { Buyer }\end{array}$ & $\begin{array}{l}\text { Required Incentive Payment to } \\
\text { Manufacturer }\end{array}$ \\
\hline 1 & $\$ 1,490$ & $\$ 1,028$ \\
\hline 2 & $\$ 1,437$ & $\$ 986$ \\
\hline 3 & $\$ 1,285$ & $\$ 882$ \\
\hline
\end{tabular}




\section{ENERGY-EFFICIENT DESIGN AND COST-EFFECTIVENESS IMPLICATIONS}

The RCDP produced an extensive database of ECM costs and energy savings, and insights into effective energy-efficient design and construction practices. The following four key design and construction findings were major results of the project:

- Duct insulation is a prerequisite to floor improvements. Duct insulation is extremely cost-effective as an energy saving measure.

- $\quad$ "Cut-In" belly blanket insulation is a very cost-effectlve way to increase the thermal performance of manufactured home floor systems. In "cut-In" installations, the belly blanket is cut and lifted into the joist cavity above the outriggers and I-beams and extended below the duct at full depth. ${ }^{(a)}$

- Blown-in insulation in the celling cavity is more cost-effective than standard attic or vault fiberglass insulation. Uninsulated spaces are reduced with the blown-in Irisulation and the material cost of blown-In insulation is usually considerably less on an equivalent performance basis than conventional fiberglass insulatlon.

- Energy-efficient windows were also a very cost-effective option. The most cost-effective window used was an argon-filled, vinyl frame, double-glazed window. Substituting these windows for standard windows created the largest overall energy savings of any ECM. However, the high cost of the windows reduced their cost-effectiveness when compared with other component improvements.

The cost and energy data from the RCDP were used to analyze the levelized costs of a wide range of ECMs, such as different insulation R-values. The only energy Impacts that were included were changes in space heating energy use. The levellzed costs were calculated taking into account interactions among the measures.

Table 6 shows that most ECMs are cost-effective compared to the Pacific Northwest's avoided electricity supply cost of 5.2 cents/kWh.

The calculated levelized costs demonstrated that all the ECMs analyzed were cost.effective, i.e., cost less than 5.2 cents per kWh saved, in the coldest climate zone The levelized costs increased in the milder climate zones.

In most regions of the country, avoided costs of electricity are likely to be at least as high $\mathrm{d}$, they are in the Paclfic Northwest. Consequently, ECMs found to be cost-effective in the RCDP are likely to be cost-effective in other regions of the country where heating loads are equal to or exceed those in the Pacific Northwest. The maasures also reduce cooling loads which might make them cost-effective in milder areas as well.

(a) For example, R-33 cut-in belly blanket insulation outperforms a system where an R-22 blanket is laid out between the heating system duct and floor joists and another R-22 blanket is laid out in the "belly" area below the duct. The resulting compression and isolation of the heating duct in the latter design considerably reduces the effectiveness of the nominal total R-44 insulation. 
TABLE 6. Levelized Conservatlon Measure Costs Based on RCDP Data $a^{(n)}$

\begin{tabular}{|c|c|c|c|c|c|}
\hline \multirow[b]{2}{*}{ Component } & \multirow[b]{2}{*}{ ECM } & \multirow{2}{*}{$\begin{array}{l}\text { Incremental } \\
\text { Retail Cost, } \\
\$ / \text { sq. ft. }\end{array}$} & \multicolumn{3}{|c|}{ Levellzed Cost, cents/kWh Saved } \\
\hline & & & Zone 1 & Zone 2 & Zone 3 \\
\hline \multirow[t]{2}{*}{ Winclows } & Vinyl frame & 10.82 & 4.0 & 2.9 & 2.5 \\
\hline & Argon filled, vinyl frame & 12.27 & 2.8 & 2.0 & 1.7 \\
\hline \multirow[t]{2}{*}{ Wall } & R-19 insulation & 0.23 & 1.0 & 0.7 & 0.6 \\
\hline & R-22 Insulation & 0.31 & 4.6 & 3.3 & 2.8 \\
\hline \multirow[t]{7}{*}{ Floor } & R-11 belly insulation & 0.09 & 0.5 & 0.4 & 0.3 \\
\hline & $\begin{array}{l}\text { R- } 11 \text { belly and R-22 } \\
\text { cavity insulation }\end{array}$ & 0.61 & 3.8 & 2.9 & 2.5 \\
\hline & $\begin{array}{l}\text { R- } 22 \text { belly and R-22 } \\
\text { cavity insulation }\end{array}$ & 0.87 & 5.4 & 3.4 & 2.9 \\
\hline & R-11 cut-in insulation & 0.09 & 0.5 & 0.4 & 0.3 \\
\hline & R-19 cut-in insulation & 0.28 & 1.1 & 0.8 & 0.7 \\
\hline & R-22 cut-in Insulation & 0.35 & 2.0 & 1.5 & 1.3 \\
\hline & R-33 cut-In insulation & 0.61 & 3.8 & 2.8 & 2.4 \\
\hline \multirow[t]{5}{*}{ Attic ceilling } & R-19 batt & 0.13 & 1.3 & 1.0 & 0.8 \\
\hline & R-30 batt & 0.40 & 2.4 & 1.8 & 1.6 \\
\hline & R-38 batt & 0.60 & 7.8 & $5.6^{(b)}$ & $4.9^{|b|}$ \\
\hline & R-49 batt & 0.88 & 8.2 & $5.9^{(b)}$ & $5.1^{(\mathrm{b})}$ \\
\hline & R-49 blown-in & 0.44 & 1.3 & 1.0 & 0.9 \\
\hline \multirow{3}{*}{$\begin{array}{l}\text { Vaulted } \\
\text { celling }\end{array}$} & R-19 batt & 0.13 & 1.3 & 1.0 & 0.8 \\
\hline & R-30 batt & 0.44 & 3.1 & 2.3 & 2.0 \\
\hline & R-38 blown-in & 0.31 & 1.1 & 0.8 & 0.7 \\
\hline Ducts & R-4 Insulation & $\$ 31$ per home & 0.2 & 0.1 & 0.1 \\
\hline
\end{tabular}

(a) Source BPA 1991a.

(b) These values were generated by the authors based on the results in BPA 1991a to make them consistent with use of an electric furnace in all cases.

\section{MARKETING ISSUES}

Manufacturers and dealers were interviewed to determine what they felt was necessary to increase buyer interest in highly energy efficlent manufactured homes. 
Manufacturers felt that continued incentlves were essential to maintain the marketability of the homes and that the potentlal for utillty blll reductions alone was not enough to assure market demand for the homes: continued incentives were essential to rnalntain the marketablity of the homes. Not only did the incentives increase buyer demand, but the increased demand stimulated dealer interest in the program. Thls caused dealers to seek education on the homes so they would be able to promote them to buyers. Who recelved the Incentives was also an important issue, since incentives to the manufacturers could achieve the same price effect as larger buyer incentives because dealers appeared to mark up wholesale prices by a fairly constant percentage (see Table 5, for example). This effect, however; should be welghed agalnst the promotlonal effects of direct incentives to the buyers.

Although the RCDP speclfications permilted glazing areas equivalent to up to $15 \%$ of the fioor area, manufacturers found that the performance requirements of the specifications usually limited the amount of glazing installed to about $13 \%$. Manufacturers said that such window and skylight area restrictlons were unappealing to potential buyers. Buyers often werent willing to reduce window area to Increase thermal performance. Manufacturers also belleved promotlons specific to SGC manufactured housing were necessary: brlefly mentioning the manufactured housing program at the end of an advertisement for stte-bullt housing was felt to be Inadequate.

Dealers were asked to rate the marketability of the RCDP homes. Given four possible options, one-third of the dealers sald the homes were "very easy" to sell, one-third said they were "somewhat easy to sell," and one-thind sald they were "somewhat difflcult" to sell. No dealers said the homes were "very difflcult" to sell (BPA 1990, p. 3).

Dealers sald the high price of the RCDP homes was often a deterrent to sales. Like manufacturers, dealers also noted consumer concerns about the window and skyllght restrictions. Dealers sald buyers were turned off by the comparatively small window area in the homes. Consumers were saild to be interested in energy efficiency, but only if it did not decrease window area or increase the cost of the home. Thus, consumers' expressed interest in energy efficiency only persisted until they had to sacrifice something for it; then it became less important (BPA 1990, p. 3).

Dealers also mentioned some key marketing factors which they felt helped sell the RCDP homes. Most Important were incentives, which helped make the price of the RCDP homes competitive with the other homes they sold. Manufacturers' support was also important, as were lower utllity bills and medla advertising. Dealers also noted that buyers percelved the energy-efflcient homes to be of higher quality than standard homes and this made the homes easler to sell.

Dealers felt that better public education tools would improve sales of the homes. They also felt a bigger sales incentive would improve sales and ralse dealer Interest in training.

Manufacturers and dealers felt the marketing effort had focused on the incentives more than the efficlency of the homes. Without a change in the focus of the advertising for the homes, problems could arise when the incentives are eliminated. In the long run, buyers have to understand the value of energy efficlency and the homes have to sell themselves. 


\section{CONCLUSIONS AND RECOMMENDATIONS}

The RCDP has demonstrated the technical feasibility of designing homes to the MCS. Manufacturers did not need to make costly production process changes to produce homes which saved between 4,000 and $8,000 \mathrm{kWh} /$ year over typlcal manufactured homes.

Average retail costs of the additlonal ECMs across the three climate zones averaged about $\$ 4,000$. The RCDP incentives helped reduce the Impact of these higher prices on consumers.

Ventilation rates for the RCDP homes and other manufactured homes were less than recornmended minimums. A number of installation and operational problems resulted in diminished Infiltration. If not corrected, adverse indoor air quality and molsture/condensation could result.

Key concerns of buyers when buying the RCDP homes included the added expense of the ECMs and how the incentives would help them with the purchase of the house, and the decreased window area of the homes, which manufacturers had used to meet the requirements. Presumed benefits by buyers included lower utllity bills and high home quallity.

A number of highly cost-effective ECMs were identifled, Including duct insulation, blown-in attic/vault Insulation, aind cut-in belly blanket insulation. Duct insulation saves so much energy given the Investment cost that it should be a required measure on all manufactured homes. Widespread use of blown-In attic/vault insulation and "cut-In" belly blanket Insulation should also be encouraged. Utillzing these measures would enable greater energy savings at a lesser cost.

Because of their higher energy efficlency, vinyl-framed windows are necessary to permit increased window area. These windows tend to be the lowest cost ones to meet the required efficlency levels. They also allow more window area to be incorporated because of their increased efficiency. Increased window area Is necessary; consumers were not willing to sacrifice slgnificant window area for energyefficiency.

Further research into efficient windows should be conducted. Two types of benefits might come from this research: 1) a more efficient window could be designed, permitting greater window area to be permilted and 2) a less costly window with good insulating properties co'sld be developed, reducing the cost of efficient wiridows to buyers.

Incentives appear to be necessary in the early stages of such programs to promote increased manufactured housing energy efficiency. Manufactures, dealers, and consumers all felt they were essential to compensate for the cost increases. In the future, if the demand for energy-efficient homes increases, the incremental cost of the ECMs should drop, reducing the need for an incentive.

Improved promotion of energy-efficient manufactured housing is also necessary. Dealers should be better informed on the measures taken to improve the homes so they can adequately inform the consumers on why the homes are better. Advertising campaigns should be targeted to manufactured 
housing. They would result in increased consumer awareness and increased demand, thus accelerating the penetration of energy-efficient manufactured housing as a whole.

With proper use of the knowledge gained from the RCDP, steps can be taken to build more elficient manufactured housing at a lesser cost. Key concerns of consumers can be addressed, and the industry can begin moving toward a higher quality, more energy-efficient product.

\section{REFERENCES}

Bonneville Power Administration (BPA). Nov 1990. "RCDP Update Technical: RCDP Studies Construction, Sale, and Set-Up of Super Good Cents Manufactured Homes." Porlland, Oregon.

Bonneville Power Administration (BPA). 1991a. Manufactured Homes Thermal Analysis and Cost Effectiveness Report. [OOE/BP-35738-4, Portland, Oregon.

Bonneville Power Administration (BPA). 1991b. "RCDP Update Technical: Studies Report Costs and Cost Effectiveness of Conservation Measures in RCDP Manufactured Homes." Portland, Oregon.

Ecotope. 1991. "Manufactured Housing Paths: Heat Loss and Heating Load Information." Seattle, Washington.

Ek, C. W., S. A. Onisko, and G. O. Gregg. 1990. "Air Leakage Tests of Manufactured Housing in the Northwest United States," ASTM-STP 1067, pp. 152-164M, H. Sherman, ed., American Society for Testing and Materials, Philadelphia, Pennsylvania.

Hadley, D. L. and S. A. Bailey. 1990. Infiltration/Nentilation Measurements in Manufactured Homes: Residential Construction Demonstration Program, PNL-7494. Pacific Northwest Laboratory, Richland, Washington.

Harkreader, S.A., A.D. Lee, and M.P. Sherman. 1987. Current Construction Practice in Pacific Northwest Manufactured Homes and Upgrade Possibilities. DOE/BP-846, Bonneville Power Administration, Portland, Oregon.

Riewer, S. and A.D. Lee. 1990. "When Manufactured Homes and Model Conservation Standards Meet." Presented at ACFEE Summer Siudy Session, 1990, Santa Cruz, California. PNL-SA-18345, Pacific Northwest Laboratory, Richland, Washington.

\section{ACKNOWLEDGMENTS}

The authors would like to acknowiedge the role played by the energy offices and manufactured home producers in Oregon, Idaho, and Washington in making the RCDP a success. They would also like to thank David Baylon and other staff members of Ecotope and Don Hadley. Pacific Northwest Laboratory, for analyzing the data and preparing the reports that are referenced in this paper. 


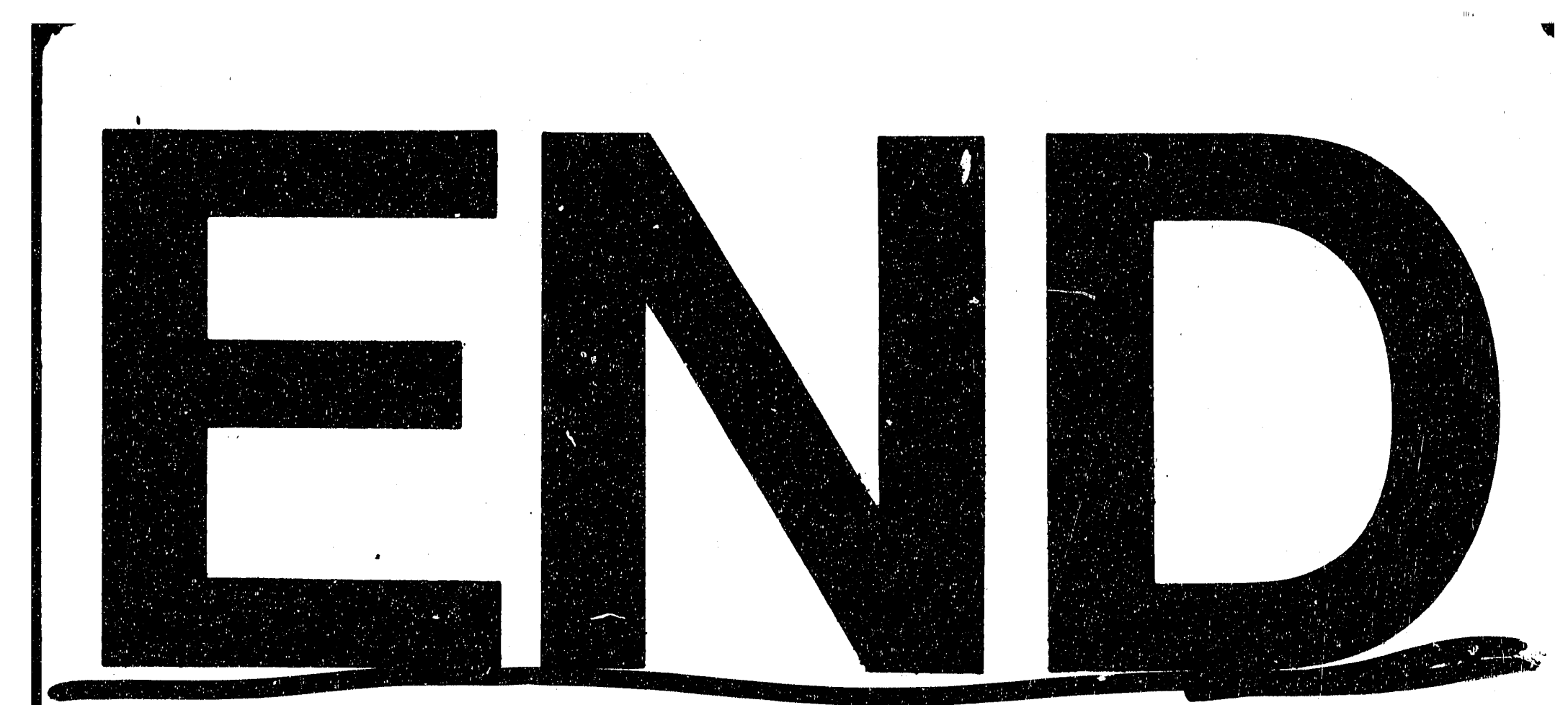




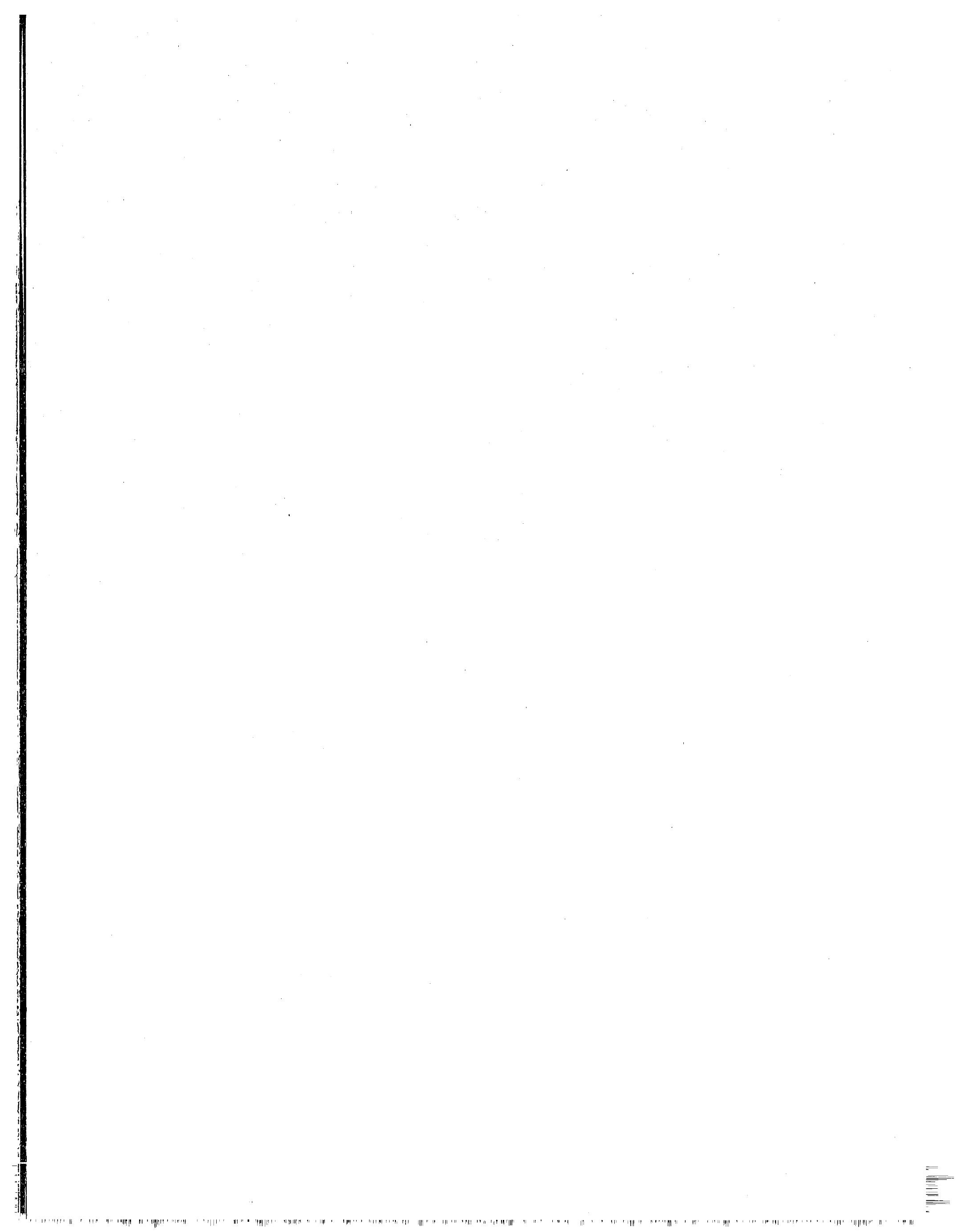

